\title{
PENGEMBANGAN LEMARI PENGERING HERBARIUM DENGAN DEHUMIDIFIER DI LABORATORIUM BIOLOGI, UNIVERSITAS BENGKULU
}

\author{
Dedi Susanto ${ }^{1)^{*}}$, Edwar ${ }^{2)}$ \\ ${ }^{1}$ PLP Laboratorium Biologi, Fakultas Matematika dan Ilmu Pengetahuan Alam \\ Universitas Bengkulu, Jl. Supratman Kandang Limun, Bengkulu, 38121 \\ *) Email: Susantod007@yahoo.com
}

\begin{abstract}
Abstrak
Salah satu kegiatan utama di Laboratorium Biologi adalah pembuatan spesimen herbarium tanaman kering. Kegiatan pembuatan herbarium dilakukan baik dalam kegiatan praktikum maupun penelitian yang dilakukan oleh dosen dan mahasiswa. Di Laboratorium Biologi, pembuatan herbarium dilakukan dengan menggunakan oven sebagai alat pengering. Sementara, saat ini di Laboratorium Biologi subLab Botani hanya terdapat 1 unit oven berkapasitas 60 liter. Hal ini menjadi salah satu hambatan pelayanan subLab Botani pada kegiatan praktikum dan penelitian, di mana ketika dilaksanakan pembuatan herbarium baik oleh kegiatan praktikum maupun oleh kegiatan penelitian terjadi waktu-tunggu yang cukup lama karena keterbatasan jumlah alat pengering yang ada. Hambatan menjadi semakin besar ketika di waktu bersamaan dilaksanakan kegiatan praktikum atau penelitian lain yang membutuhkan oven juga. Solusi utama dari permasalahan ini adalah pengadaan oven yang baru, namun ini bukan hal yang mudah terlaksana karena harga oven laboratorium berkapasitas besar relatif mahal. Selain itu kapasitas oven yang hanya sekira $60 \mathrm{~L}$ hanya mampu menampung sejumlah kecil spesimen tanaman dalam satu kali proses pengeringan. Karena itulah, penulis berupaya mencari solusi alternatif dengan merancang lemari pengering yang memiliki kapasitas muat $2 \mathrm{x}$ dari oven yang selama ini telah digunakan. Sebagai alat pengering digunakan paduan dari alatdehumifier (sebagai penyerap uap air) dan kipas (sebagai pengatur sirkulasi udara).
\end{abstract}

Kata Kunci : herbarium, lemari pengering, dehumidifier

\begin{abstract}
One of the main activities in the Biology Laboratory is the drying process of the plant speciments to be herbarium specimens. The process hold both in practicum and research activities are carried out by lecturers and students. In the Biology Laboratory, the herbarium is made using an oven as a drying tool. Meanwhile, currently in the Biology Laboratory of the Botanical sub-Lab there is only one oven with a capacity of 60 liters. This make the time to finish herbarium drying process take a long period both in practicum and research activities. The problem become even greater when some activities need the oven in the same time. The main solution to this problem is the procurement of a new oven, but this is not an easy thing to do because the price of a large capacity laboratory oven is expensive. In addition, the capacity of the oven which is only approximately $60 \mathrm{~L}$ is only able to accommodate a small number of plant specimens in one drying process. Therefore, the author tries to find an alternative solution by designing a drying cabinet that has a capacity of twice the oven that has been used so far. As a dryer tool for use, a combination of a dehumifier (as an absorber of water vapor) and a fan (as a regulator of air circulation) is used.
\end{abstract}

Keywords: herbarium, drying cabinet, dehumidifier

\section{PENDAHULUAN}

Herbarium dibuat melalui serangkaian cara yang lazim dilakukan, yaitu : 1) mengumpulkan bagian-bagian tumbuhan yang ingin dijadikan herbarium, 2) menata bagian-bagian tumbuhan di alat press, 3) melakukan proses pengeringan, 4) meletakkan spesimen tumbuhan yang telah kering di atas lembar karton, 5) menyimpan herbarium di lemari penyimpanan (Alexey Shipunov : 2019). Adapun detail teknis pelaksanaan pembuatan herbarium bisa berbeda-beda antara satu peneliti dengan peneliti yang lain, antara satu daerah dengan daerah yang lain. Misalnya, sasak yang dipergunakan sebagai alat-pres bisa saja berbentuk dua lembar papan triplek/multiplek (Western Australian Herbarium : 2008), bisa juga terbuat dari kayu-kayu kecil yang disusun membentuk persegi-empat (Kottapalli Seshagirirao : 2016 ), dan bisa juga terbuat dari kerangka kayu yang di bagian tengahnya dipasang kasa besi (Alexey Shipunov : 2019). Contoh lain, plat ventilator bisa terbuat dari kardus bergelombang (kertas kardus di bagian tengahnya terdapat rongga udara), dan bisa juga terbuat dari plat seng bergelombang (K. Maden : 2004).

Selain beberapa contoh di atas, pengeringan spesimen herbarium juga bisa dikategorikan secara umum menjadi dua bentuk : 1) pengeringan tanpa menggunakan pemanas buatan, 2) pengeringan dengan bantuan pemanas buatan. (K. Maden : 2004). Pengeringan tanpa pemanas buatan dikenal juga sebagai metode "berkeringat", yaitu menata spesimen herbarium di dalam alat pres, lalu membiarkannya selama 24 jam untuk kemudian mengganti kertas hisap dengan yang baru, begitu seterusnya sampai spesimen tanaman menjad 
kering. Pengeringan tanpa pemanas buatan akan semakin efektif apabila dilakukan di luar ruangan karena faktor aliran udara (angin) dapat membantu proses pengeringan. Pengeringan tanpa pemanas buatan memungkinkan dilakukan apabila kondisi lingkungan yang mendukung, misalnya cuaca yang cerah dan kondisi kelembaban yang kering (Alexey Shipunov : 2019). Jika kondisi luar ruangan tidak memungkinkan, pengeringan tanpa pemanas buatan bisa dilakukan dengan meletakkan paket-pres di dalam lemari atau rak yang mendapatkan aliran udara buatan (Royal Horticultura Society : 2013). Adapun pengeringan dengan pemanas buatan lebih bervariasi dengan beberapa alternatif sumber panas yang dapat digunakan seperti kompor, oven atau ruang pengering lainnya (D.P. Semwal, dkk).

Dengan demikian, penggunaan pemanas buatan dalam pembuatan herbarium bukanlah sebuah keharusan. Hal yang paling pokok dalam pembuatan herbarium adalah spesimen tanaman dapat mengering dengan kondisi terbaik, di mana warna dan keadaan fisik spesimen terjaga dengan baik. Untuk proses pengeringan tanpa pemanas buatan, tentu saja disyaratkan kondisi lingkungan yang mendukung, terutama adalah udara dengan kelembaban rendah. Untuk proses pengeringan dengan pemanas buatan, pengaturan suhu dan lama pemanasan harus diperhatikan karena suhu yang terlalu tinggi akan merusak tanaman (menjadi hangus-kehitaman).

Metode pembuatan herbarium yang telah dijalankan di Laboratorium Biologi sub lab Botani adalah dengan menggunakan oven sebagai sumber panas buatan dengan pengaturan suhu bervariasi antara $45-50^{\circ} \mathrm{C}$ tergantung jenis tanaman yang dikeringkan. Metode pengeringan tanpa pemanas buatan selama ini tidak dilakukan karena kondisi lingkungan yang kurang mendukung, di antaranya adalah curah hujan yang tinggi dan kelembaban yang tinggi (rerata lebih dari 80\%). Penggunaan oven sebagai sumber panas buatan ini memiliki beberapa kendala, yaitu : 1) Jumlah oven yang sedikit. Seiring berjalannya waktu, jumlah oven yang tersedia semakin berkurang karena beberapa oven yang mengalami kerusakan. Saat ini, hanya tersedia satu oven yang dapat digunakan untuk mengeringkan herbarium di Laboratorium Biologi sub Lab Botani, 2) Oven adalah alat umum yang dibutuhkan banyak praktikum dan penelitian, sehingga pembuat herbarium harus berbagi waktu dengan praktikan dan peneliti yang lain dalam penggunaan oven.

Berdasarkan prinsip-prinsip umum pembuatan herbarium di atas, penulis merangkum beberapa poin penting dalam pembuatan herbarium : 1) kebutuhan pemanas tinggi bukanlah keharusan, 2) pembuatan herbarium dapat dilakukan dengan panas rendah dalam udara yang kering (kelembaban rendah), 3) keberadaan aliran udara dapat membantu proses pengeringan spesimen-herbarium. Dengan 3 prinsip inilah penulis merancang lemari pengering sebagai solusi keterbatasan oven di Laboratorium Biologi sub Lab Botani. Penulis berencana membuat lemari pengering yang memadukan tiga unsur : 1) pemanas ringan, 2) udara kering, dan 3) aliran udara.

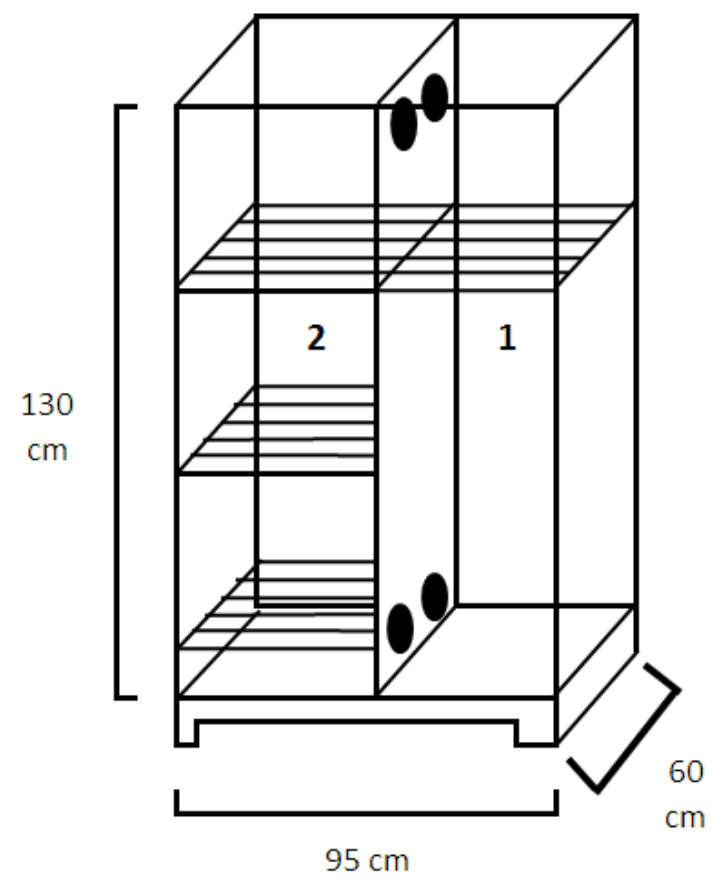

Gambar 1. Skema dan dimensi rancangan lemari-pengering 


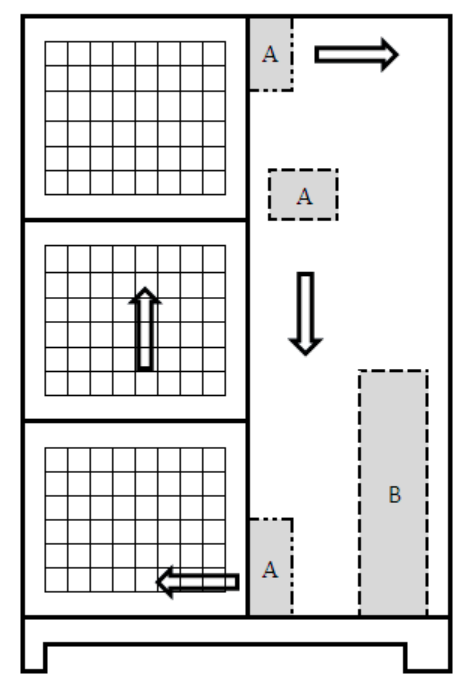

Gambar 2. Skema alur aliran udara dalam lemari-pengering

Pemanas ringan yang akan penulis gunakan bersumber dari beberapa peralatan elektronik itu sendiri yang terdiri dari dehumidifier dan kipas angin. Hal ini disebabkan peralatan elektronik ini dalam pengoperasiannya menghasilkan panas ringan, yang akan diuji apakah sudah memadai untuk proses pengeringan herbarium.Udara kering dalam lemari pengering akan diciptakan oleh alat dehumidifier yang dijual di pasaran. Dehumidifier yang dipergunakan adalah Dehumidifier 16 L BEIGE Kris.

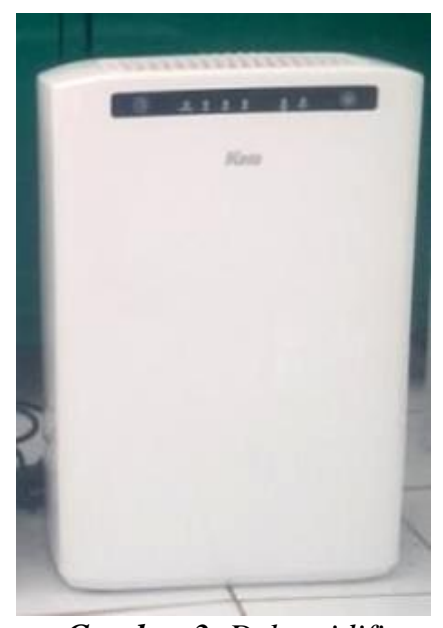

Gambar 3. Dehumidifier

Penggunaan alat dehumidifier yang dijual di pasaran ini bertujuan untuk mendapatkan alat dehumidifier yang murah dan mudah didapatkan, sehingga apabila suatu hari terjadi kerusakan pada alat tersebut, dapat dengan mudah dicari penggantinya tanpa harus melakukan pemesanan secara khusus ke suplaier alat laboratorium. Alat dehumidifier pada prinsipnya adalah alat yang menghilangkan uap air dari udara dengan mengembunkannya dan mengumpulkannya di dalam sebuah kontainer (www.mesinraya.co.id). Dengan merubah uap air menjadi aircairan, maka kadar uap air di udara akan berkurang dan udara akan menjadi relatif kering. Kemampuan alat dehumidifier menghilangkan kelembaban udara berbeda-beda tergantung luas ruangan, bahan baku dinding, dan kadar kelembaban ruangan akibat keberadaan sumber air. Dengan demikian, dehumidifier yang bekerja pada ruangan yang kecil berdinding solid, seperti lemari-plat-besi, tentu akan bekerja lebih maksimal. Bahkan, dalam skala ruang yang kecil, dehumidifier dapat bekerja lebih dari sekedar mengurangi kelembaban udara, tapi juga dapat mengeringkan benda-benda yang ada di dalamnya (www.mesinraya.co.id). Potensi inilah yang akan diteliti pada penelitian kali ini. Alat dehumidifier lebih efektif bekerja di suhu hangat dari pada suhu rendah (sejuk) sehingga perpaduan antara pemanas-ringan dengan dehumidifier diharapkan dapat menjadi kolaborasi yang baik. Adapun aliran udara akan dibuat dengan memasang kipas di lemari-pengering. 


\section{METODE}

Penelitian ini merupakan penelitian eksperimen dengan 1 (satu) faktor, yaitu proses pembuatan herbarium berdasarkan jumlah spesimen untuk menguji nikerja lemari-pengering pada kapasitas minimum hingga kapasitas maksimum. Uji coba lemari-pengering dilakukan dalam 4 tahap dengan jumlah spesimen yang berbeda-beda, yaitu :

1) Uji coba tahap $1: 30$ spesimen dengan 10 spesimen dalam sepasang sasak

2) Uji coba tahap $2: 30$ spesimen dengan 5 spesimen dalam sepasang sasak.

3) Uji coba tahap $3: 45$ spesimen dengan 5 spesimen dalam sepasang sasak.

4) Uji coba tahap 4:60 spesimen dengan 5 spesimen dalam sepasang sasak.

Alat yang digunakan dalam penelitian ini adalah : 1) lemari pengering, 2) stop kontak timer, 3) sasak, 4) sprayer, 5) neraca analitik, 6) kipas.

Bahan yang digunakan dalam penelitian ini adalah : 1) alkohol $70 \%$, 2) tanaman sirih, 3) koran, 4) kardus, 5) tali rafia.

Langkah-langkah uji coba yang dilakukan adalah :

1) Mempersiapkan spesimen sejumlah masing-masing tahapan.

2) Memotong spesimen tanaman sirih sesuai ukuran sasak.

3) Menimbang berat basah masing-masing spesimen tanaman sirih.

4) Meletakkan spesimen dalam sasak dengan urutan : a) sasak, b) kardus, c) kertas koran, d) spesimen, e) kertas koran, f) kardus, g) sasak, dengan meletakkan kertas koran sebagai pemisah di antara setiap spesimen tumbuhan.

5) Memasukkan spesimen ke dalam lemari pengering, menyalakan dehumidifier pada mode $40 \%$

6) Menimbang berat masing-masing spesimen tanaman sirih setelah 24 jam, 2x24 jam, 3x24 jam dan 4x24 jam.

7) Mengambil foto spesimen

8) Menghitung kadar air yang hilang selama proses uji coba.

Dari langkah-langkah di atas maka akan didapatkan beberapa data sebagai berikut :

1) Data kuantitatif, yaitu data yang menunjukkan kadar air yang diuapkan selama proses uji coba.

2) Data visual, yaitu tampilan morfologis spesimen herbarium.

3) Grafik laju pengeringan yang memperlihatkan aliran proses pengeringan spesimen selama uji coba.

Penelitian dilakukan di Laboratorium Biologi, FMIPA Universitas Bengkulu. Penelitian dilakukan pada bulan Juli - Oktober 2021.

\section{HASIL DAN PEMBAHASAN}

1) Data kuantitatif

Data hasil uji coba lemari-pengering dapat dilihat pada tabel-tabel berikut ini :

Tabel 1. Persentase penguapan dalam uji coba tahap 1

\begin{tabular}{|l|c|c|c|c|}
\hline \multirow{2}{*}{ No. Spesimen } & \multicolumn{4}{|c|}{ Kadar Air yang Diuapkan (\%) } \\
\cline { 2 - 5 } & $\begin{array}{c}\mathbf{2 4} \\
\text { jam }\end{array}$ & $\begin{array}{c}\mathbf{4 8} \\
\text { jam }\end{array}$ & $\begin{array}{c}\mathbf{7 2} \\
\text { jam }\end{array}$ & $\begin{array}{c}\mathbf{9 6} \\
\text { jam }\end{array}$ \\
\hline Sasak bawah & 38,50 & 54,06 & 69,83 & 77,06 \\
\hline Sasak tengah & 35,70 & 50,61 & 63,79 & 72,06 \\
\hline Sasak atas & 30,76 & 46,54 & 61,31 & 70,47 \\
\hline Rerata & 34,99 & 50,40 & 64,98 & 73,20 \\
\hline
\end{tabular}

Tabel 2. Persentase penguapan dalam uji coba tahap 2.

\begin{tabular}{|l|c|c|c|c|}
\hline \multirow{2}{*}{ No. Spesimen } & \multicolumn{4}{|c|}{ Kadar Air yang Diuapkan (\%) } \\
\cline { 2 - 5 } & $\begin{array}{c}\mathbf{2 4} \\
\text { jam }\end{array}$ & $\begin{array}{c}\mathbf{4 8} \\
\text { jam }\end{array}$ & $\begin{array}{c}\mathbf{7 2} \\
\text { jam }\end{array}$ & $\begin{array}{c}\mathbf{9 6} \\
\text { jam }\end{array}$ \\
\hline Sasak bawah & 60,76 & 76,11 & 80,39 & 80,94 \\
\hline Sasak tengah & 46,94 & 69,35 & 77,39 & 80,24 \\
\hline Sasak atas & 48,72 & 69,82 & 78,42 & 80,74 \\
\hline Rerata & 52,14 & 71,76 & 78,73 & 80,64 \\
\hline
\end{tabular}

Tabel 3. Persentase penguapan dalam uji coba tahap 3. 


\begin{tabular}{|l|c|c|c|c|}
\hline \multirow{2}{*}{ No. Spesimen } & \multicolumn{4}{|c|}{ Kadar Air yang Diuapkan (\%) } \\
\cline { 2 - 5 } & $\mathbf{2 4}$ jam & $\mathbf{4 8}$ jam & $\mathbf{7 2 ~ j a m}$ & $\mathbf{9 6}$ jam \\
\hline Sasak Bawah & 64.11 & 78.29 & 78.96 & 79.92 \\
\hline Sasak Tengah & 58.36 & 77.59 & 80.28 & 81.64 \\
\hline Sasak Atas & 62.02 & 76.65 & 78.38 & 79.31 \\
\hline Rerata & 61.50 & 77.51 & 79.21 & 80.29 \\
\hline
\end{tabular}

Tabel 4. Persentase penguapan dalam uji coba tahap 4.

\begin{tabular}{|l|c|c|c|c|}
\hline \multirow{2}{*}{ No. Spesimen } & \multicolumn{4}{|c|}{ Kadar Air yang Diuapkan (\%) } \\
\cline { 2 - 5 } & $\begin{array}{c}\mathbf{2 4} \\
\text { jam }\end{array}$ & $\begin{array}{c}\mathbf{4 8} \\
\text { jam }\end{array}$ & $\begin{array}{c}\mathbf{7 2} \\
\text { jam }\end{array}$ & $\begin{array}{c}\mathbf{9 6} \\
\text { jam }\end{array}$ \\
\hline Sasak Bawah & 54,11 & 74,01 & 79,26 & 81,48 \\
\hline Sasak Tengah & 52,28 & 71,09 & 77,08 & 80,37 \\
\hline Sasak Atas & 50,24 & 69,44 & 76,04 & 80,19 \\
\hline Rerata & 52,21 & 71,51 & 77,46 & 80,68 \\
\hline
\end{tabular}

2) Data visual

Foto spesimen herbarium hasil uji coba dapat dilihat sebagai berikut :

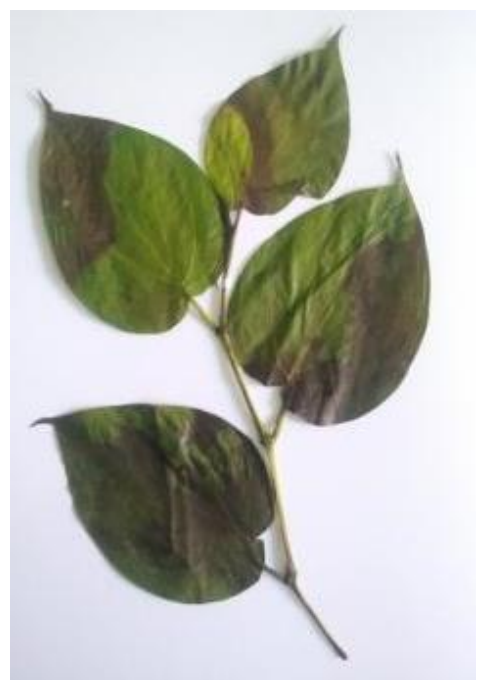

Gambar 4. Uji coba tahap 1

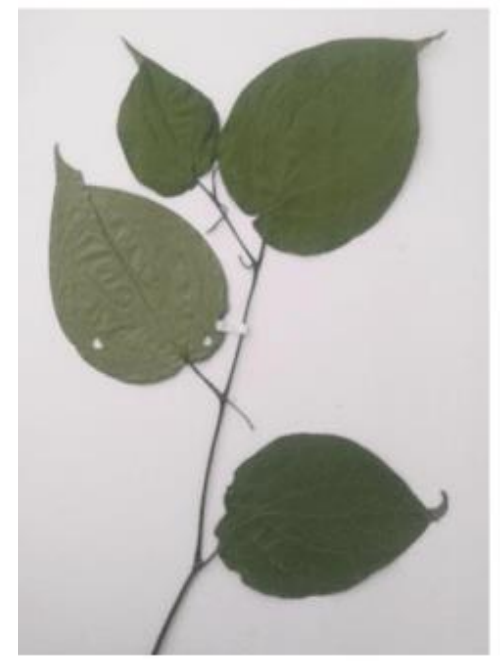

Gambar 5. Uji coba tahap 2 


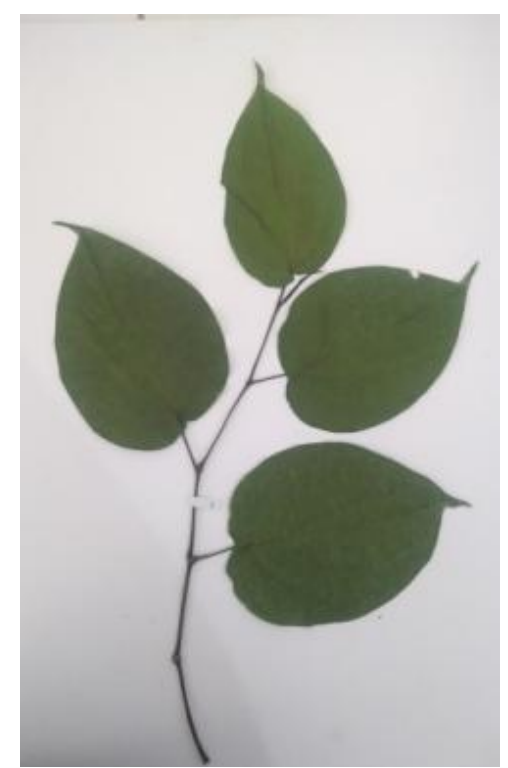

Gambar 6. Uji coba tahap 3

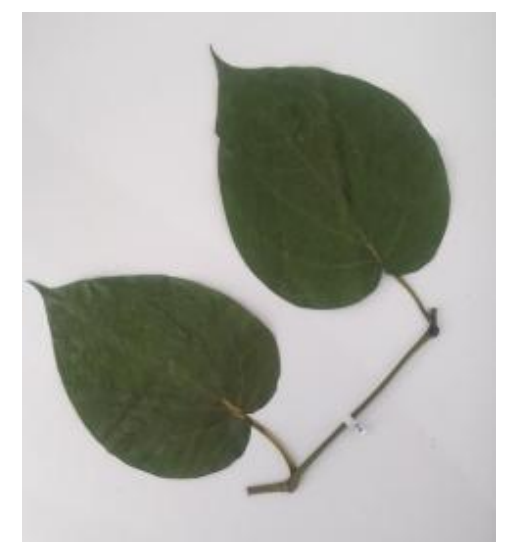

Gambar 7. Uji coba tahap 4

\section{3) Analisa grafik laju penguapan}

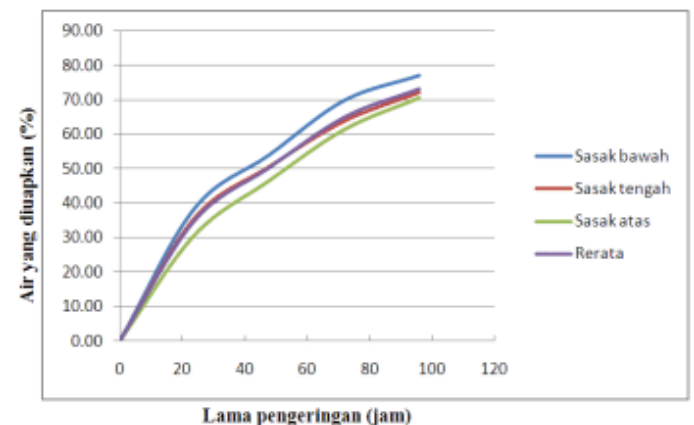

Gambar 8. Grafik laju penguapan uji coba tahap 1

Pada uji coba tahap 1 didapatkan laju penguapan yang kurang stabil. Hal ini terlihat dari grafik yang bergelombang. Bentuk gelombang yang serupa antara sasak yang berada di atas, tengah dan bawah menunjukkan bahwa hasil ini konsisten.

Selain dari bentuknya yang menunjukkan ketidakstabilan, data kuantitatif juga menunjukkan proses pengeringan yang lambat. 24 jam pertama proses pengeringan hanya berhasil menguapkan sekira $35 \%$ kadar air, dilanjutkan 24 jam kedua hanya mampu menguapkan sekira $50 \%$ kadar air. 24 jam ketiga dan keempat masingmasing berhasil menguapkan sekira 65 dan $73 \%$ kadar air.

Sebenarnya, persentase ini tidak merata terjadi pada semua spesimen. Spesimen yang berada pada lapisan luar (lapisan 1-3 terluar) cenderung memiliki kadar penguapan yang cukup tinggi, sementara spesimen yang berada di lapisan dalam (4 lapisan di tengah) cenderung memiliki kadar penguapan yang jauh lebih rendah. Berikut 
ini adalah contoh dari perbedaan kadar penguapan spesimen lapisan terluar dengan spesimen lapisan tengah pada sasak. 
Tabel 5. Perbedaan laju penguapan pada spesimen terluar dengan spesimen tengah lapisan sasak

\begin{tabular}{|l|c|c|c|c|c|c|c|c|}
\hline \multirow{3}{*}{ No. Spesimen } & \multicolumn{8}{|c|}{ Kadar Air yang Diuapkan (\%) } \\
\cline { 2 - 10 } & \multicolumn{2}{|c|}{$\mathbf{2 4}$ jam } & \multicolumn{2}{c|}{ 48 jam } & \multicolumn{2}{c|}{$\mathbf{7 2}$ jam } & \multicolumn{2}{c|}{$\mathbf{9 6}$ jam } \\
\cline { 2 - 9 } & Pinggir & Tengah & Pinggir & Tengah & Pinggir & Tengah & Pinggir & Tengah \\
\hline Sas ak bawah & 47,86 & 24,47 & 64,01 & 39,13 & 77,53 & 55,18 & 81,82 & 66,26 \\
\hline Sas ak tengah & 44,18 & 22,98 & 60,37 & 35,98 & 71,67 & 51,96 & 77,09 & 64,52 \\
\hline Sas ak atas & 35,74 & 23,29 & 53,46 & 36,15 & 68,69 & 50,24 & 76,05 & 62,1 \\
\hline Rerata & 42,59 & 23,58 & 59,28 & 37,09 & 72,63 & 52,46 & 78,32 & 64,29 \\
\hline
\end{tabular}

Pada tabel di atas terlihat bahwa pada 24 jam pertama, spesimen terluar menghasilkan penguapan sekira 42 $\%$ sedangkan spesimen tengah menghasilkan penguapan sekira $23 \%$. Terdapat selisih hingga $19 \%$ antara penguapan spesimen terluar dengan spesimen tengah. Pada 24 jam kedua, spesimen terluar menghasilkan penguapan sekira $59 \%$ sedangkan spesimen tengah menghasilkan penguapan sekira $37 \%$. Terdapat selisih sekira $22 \%$ antara penguapan spesimen terluar dengan spesimen tengah. Data ini menunjukkan peningkatan selisih antara kedua spesimen. Pada 24 jam ketiga, spesimen terluar menghasilkan penguapan sekira $72 \%$ sedangkan spesimen tengah menghasilkan penguapan sekira $52 \%$. Terdapat selisih sekira $20 \%$ antara kedua spesimen. Pada 24 jam ketiga, spesimen terluar menghasilkan penguapan sekira $78 \%$ sedangkan spesimen tengah menghasilkan penguapan sekira $64 \%$. Terdapat selisih sekira $14 \%$. Dengan demikian dalam seluruh proses terdapat perbedaan antara 14-22\% antara penguapan spesimen terluar dengan spesimen tengah.

Selain data kuantitatif di atas, perbedaan juga terlihat dari fisik spesimen terluar dengan spesimen tengah. Pada lapisan terluar kondisi spesimen dan kertas koran cenderung lebih kering. Sebaliknya, spesimen tengah kondisinya cenderung lembab dengan kertas koran yang sangat lembab. Hal ini terjadi karena spesimen terluar lebih mudah melepaskan uap air ke udara mengikuti aliran proses pengeringan, sementara uap air di spesimen tengah lebih sulit terlepas ke udara karena memiliki penyekat lebih banyak yang menyebabkan sebagian uap air terjebak di dalam kertas koran.

Kondisi ini menunjukkan proses pengeringan tidak berjalan dengan baik disebabkan oleh lapisan spesimen yang tebal. Kondisi yang tidak baik ini sangat terlihat secara visual pada foto spesimen hasil uji coba tahap 1. Pada foto tersebut terlihat kondisi spesimen yang lembab, kondisi warna yang tidak konsisten, di mana sebagian sangat menghitam sementara sebagian lagi sangat hijau karena lembab. Hal ini mengindikasikan bahwa spesimen yang dihasilkan tidak baik untuk disimpan sebagai herbarium.

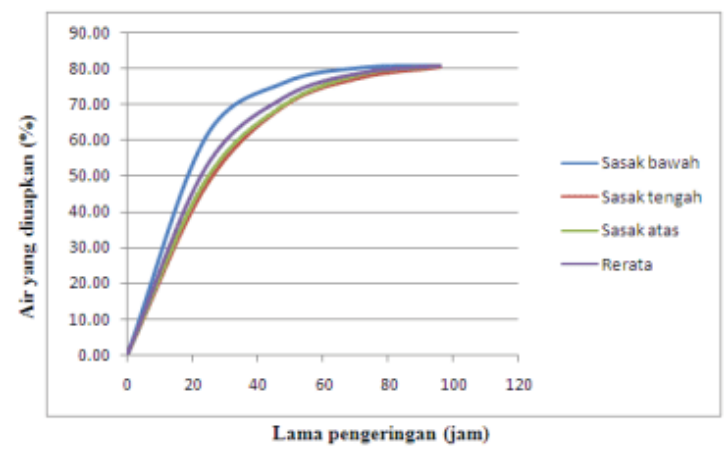

Gambar 9. Grafik laju penguapan uji coba tahap 2

Uji coba tahap 2 dilakukan dengan mengurangi jumlah spesimen per pasang sasak, sementara jumlah total spesimen dalam lemari pengering tetap. Pada uji coba tahap 2, telah didapatkan kondisi spesimen yang stabil yang diindikasikan oleh beberapa indicator sebagai berikut :

a) Kondisi kering spesimen pada semua lapisan cenderung merata.

b) Kondisi kertas koran di setiap lapisan tidak berbeda jauh. Beberapa kertas koran di bagian tengah terasa sedikit lebih lembab daripada kertas koran di lapisan luar, tapi dengan perbedaan yang sedikit.

c) Hasil penimbangan berat spesimen yang sedikit bervariasi namun tidak menunjukkan perbedaan yang jauh antara spesimen yang berada di lapisan luar dan lapisan dalam. Berikut ini adalah contoh data laju pengeringan dari salah satu pasang sasak.

Tabel 6. Laju pengeringan spesimen dari salah satu pasang sasak

\begin{tabular}{|r|c|c|c|c|}
\hline \multirow{2}{*}{ No. Spesimen } & \multicolumn{4}{|c|}{ Kadar Air yang Diuapkan (\%) } \\
\cline { 2 - 5 } & $\mathbf{2 4}$ jam & $\mathbf{4 8}$ jam & $\mathbf{7 2}$ jam & $\mathbf{9 6}$ jam \\
\hline 1 & 71.07 & 79.29 & 81.59 & 81.92 \\
\hline 2 & 62.10 & 77.27 & 80.72 & 80.94 \\
\hline 3 & 63.00 & 77.35 & 80.34 & 80.43 \\
\hline 4 & 68.04 & 79.29 & 82.38 & 82.74 \\
\hline 5 & 70.78 & 79.25 & 81.44 & 81.65 \\
\hline
\end{tabular}


Tabel di atas menunjukkan bahwa pada 24 jam pertama berhasil dilakukan proses penguapan antara 62 - $71 \%$. Data ini menunjukkan selisih $9 \%$ antara proses penguapan tertinggi dengan proses penguapan terendah. Pada 24 jam selanjutnya selisih ini selalu berkurang, yaitu hanya $2 \%(77-79 \%)$ pada 24 jam kedua, $2 \%(80-82 \%)$ pada 24 jam ketiga, dan $2 \%(80-82 \%)$ pada 24 jam keempat.

d) Grafik di atas telah menunjukkan perubahan yang signifikan. Apabila grafik pertama menunjukkan grafik yang bergelombang, maka grafik kedua ini berupa kurva yang konsisten. Selain itu, perbedaan lainnya terlihat dari grafik pertama yang cenderung flat/datar sementara grafik kedua memperlihatkan kurva yang melengkung. Data dari tiga jenis sasak secara konsisten menunjukkan kurva ini.

e) Salah satu faktor terpenting untuk menilai proses ini adalah kondisi visual spesimen setelah proses pengeringan dilakukan. Pada foto spesimen hasil uji coba tahap 2 dapat dilihat bahwa spesimen yang dihasilkan cenderung memiliki warna yang konsisten dan merata, baik dari muka daun maupun belakang daun. Demikian juga warna spesimen mampu mempertahankan warna tumbuhan segar hingga sekira 80 $\%$ dari aslinya. Hasil ini mengindikasikan bahwa uji coba tahap 2 ini telah berhasil menghasilkan spesimen herbarium yang baik.

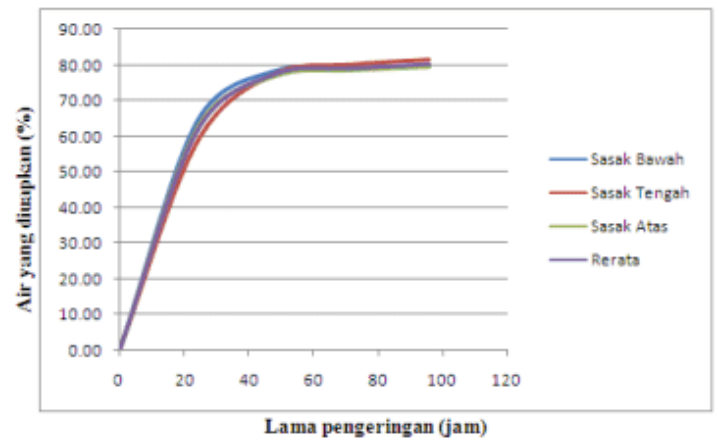

Gambar 10. Grafik laju penguapan uji coba tahap 3

Prinsip dari uji coba tahap 3 serupa dengan uji coba tahap 2 di mana jumlah spesimen per pasang sasak adalah 5. Pada uji coba tahap 3 ini penulis meningkatkan kapasitas dari uji coba tahap 2 sebanyak 30 spesimen menjadi 45 spesimen untuk menganalisa kinerja lemari-pengering pada kapasitas yang lebih padat.

Hasil dari uji coba tahap 3 cenderung memperlihatkan kekonsistenan yang serupa dengan uji coba tahap 2 dalam beberapa indikator : 1) kondisi kering spesimen di setiap lapisan yang cenderung merata, 2) kondisi kering kertas koran yang tidak berbeda jauh antara kertas koran di pinggir dan di tengah, 3) selisih penguapan yang kecil antara spesimen luar dan spesimen tengah (selisih penguapan akhir sekira maksimal $5 \%$ ), 4) Grafik yang sangat konsisten antara 3 jenis sasak, 5) Foto spesimen hasil uji coba tahap 3 yang sangat baik.

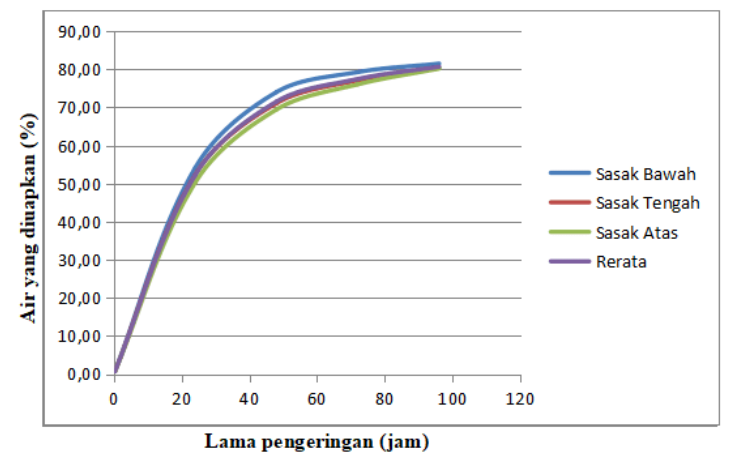

Gambar 11. Grafik laju penguapan uji coba tahap 4

Prinsip dari uji coba tahap 4 serupa dengan uji coba tahap 2 di mana jumlah spesimen per pasang sasak adalah 5. Pada uji coba tahap 4 ini penulis meningkatkan kapasitas dari uji coba tahap 2 sebanyak 30 spesimen menjadi 60 spesimen untuk menganalisa kinerja lemari-pengering pada kapasitas yang lebih padat.

Hasil dari uji coba tahap 4 cenderung memperlihatkan kekonsistenan yang serupa dengan uji coba tahap 2 dalam beberapa indikator : 1) kondisi kering spesimen di setiap lapisan yang cenderung merata, 2) kondisi kering kertas koran yang tidak berbeda jauh antara kertas koran di pinggir dan di tengah, 3) selisih penguapan yang kecil antara spesimen luar dan spesimen tengah (selisih penguapan akhir sekira maksimal $2 \%$ ), 4) Grafik yang sangat konsisten antara 3 jenis sasak, 5) Foto spesimen hasil uji coba tahap 3 yang sangat baik. 


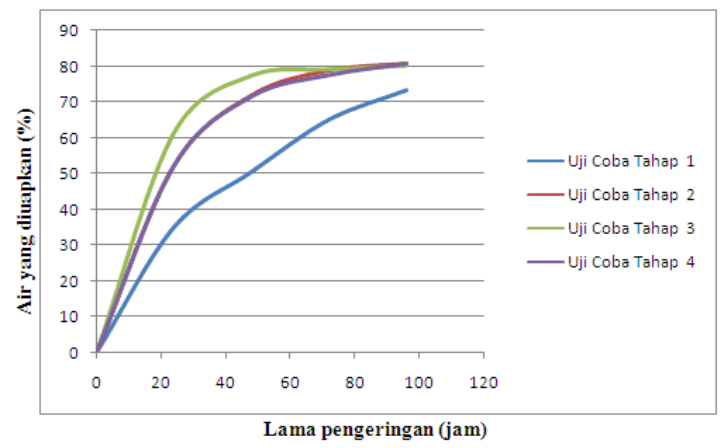

Gambar 12. Grafik perbandingan grafik laju penguapan uji coba tahap 1 - 4

Grafik ke-5 ini membandingkan hasil uji coba tahap 1, uji coba tahap 2, uji coba tahap 3 dan uji coba tahap 4. Pada perbandingan ini terlihat bahwa uji coba tahap 1 memiliki kinerja yang paling rendah dengan bentuk grafik yang sangat berbeda. Uji coba tahap 2 dan uji coba tahap 4 memperlihatkan grafik yang sangat mirip hingga berimpitan satu sama lain. Hal ini memberikan indikasi yang positif bahwa lemari-pengering bekerja dengan baik pada kapasitas yang kecil maupun besar. Uji coba tahap 3 memberikan grafik yang serupa dengan uji coba tahap 2 dan uji coba tahap 4, namun dengan grafik yang lebih tinggi yang menunjukkan kinerja penguapan yang lebih baik. Kinerja yang lebih tinggi ini kemungkinan muncul sebagai akibat dari kinerja dehumidifier yang sesaat lebih tinggi, karena dehumidifier sempat bekerja pada mode continous atau kinerja maksimalnya, sementara pada umumnya dehumidifier ini dioperasikan pada mode $40 \%$.

\section{KESIMPULAN}

Dari penelitian ini penulis mengambil beberapa kesimpulan sebagai berikut :

1. Lemari-pengering yang penulis rancang bekerja dengan baik sesuai peruntukannya dalam pembuatan herbarium.

2. Pembuatan herbarium dengan 10 spesimen dalam satu pasang sasak menghasilkan herbarium yang tidak baik.

3. Pembuatan herbarium dengan 5 spesimen dalam satu pasang sasak menghasilkan herbarium yang baik.

4. Lemari-pengering dapat bekerja dengan baik pada kapasitas tinggi.

\section{UCAPAN TERIMA KASIH}

Terima kasih kami sampaikan kepada Kementerian Pendidikan, Kebudayaan, Riset dan Teknologi yang telah membantu dan mendanai kegiatan ini sesuai nomor kontrak 179.5/E4.3/TA.03.01/2021 sehingga kegiatan penelitian pengembangan laboratorium ini dapat terlaksana.

\section{DAFTAR PUSTAKA}

---. 2009. Preparing And Storing Herbarium Specimens. National Park Service. Https://Www.Nps.Gov/Museum/Publications/Conserveogram/11-12.Pdf

---. 2013. RHS Herbarium Guide To Making Herbarium Specimens. Royal Horticultura Society (RHS). Https://Www.Plantheritage.Org.Uk/Media/1894/Rhs-Guide-To-Making-Herbarium-Specimens.Pdf

---. 2008. How To Collect Herbarium Specimens : A Guide. Prepared By The Western Australian Herbarium. Department Of Biodiversity, Conservation And Attraction, Government Of Western Australia. Https://Www.Dpaw.Wa.Gov.Au/Images/Documents/PlantsAnimals/Herbarium/How To_Collect_Herbarium_Specimens.Pdf

---. 1992. Cara Uji Makanan dan Minuman. 1992. SNI 01-2891-1992. Badan Standardisasi Nasional. Jakarta.

Alexey Shipunov. 2019. How To Make Herbarium : A Short Manual. Http://Ashipunov.Info/Shipunov/School/Biol_448/Herbarium/Herbarium.Pdf

D.P. Semwal, Anjula Pandey And Rita Gupta. Introduction To Procedures For Preparing Herbarium Specimens Of Cultivated Plants. Http://Www.Nbpgr.Ernet.In/Training_Management_Pgr/Compendium/32_Introduction_To_Procedur es_For_Prepairing_Herbarium_Specimens_Dp_Semwal.Pdf

Dedi Susanto, Lies Winarsih, Rochmah Supriati. 2020. Perbandingan Penggunaan Sasak Berbahan Kayu Dan Besi Terhadap Kecepatan Pengeringan Herbarium Di Laboratorium Biologi, Universitas Bengkulu. Jurnal Pengelolaan Laboratorium Sains dan Teknologi. Vol. 1 No.1 Tahun 2020, hal. 25-33. Universitas Bengkulu. 
Heri Sujadmiko, Drs., M.Si., Susarsi Sabbithah, Dra., \& Sri Sulastri, Dra. 2012. Praktikum Taksonomi Tumbuhan Rendah (Edisi 2). Modul 1 : Koleksi Tumbuhan Alga Dan Lumut. Universitas Terbuka. Tangerang Selatan.

K. Maden. 2004. Plant Collection And Herbarium Techniques. Nepal Journals Online Vol. 2 No. 1 (2004). Https://Www.Nepjol.Info/Index.Php/On/Article/View/327

Kottapalli Seshagirirao, dkk.2016. Preparation Of Herbarium Specimen For Plant Identification And Voucher Number. $\quad$ Roxburghia 6(1-4) : 2016. Https://Research.Reading.Ac.Uk/Herbarium/Our-Research/How-To-Make-A-Herbarium-Specimen/

Loran C. Anderson. 1999. Collecting And Preparing Plant Specimens And Producing An Herbarium. Able Vol. 20 Chapter 16. Https://Www.Ableweb.Org/Biologylabs/Wp-Content/Uploads/Volumes/Vol-20/16Anderson.Pdf

Sugiyono. 2006. Metode Penelitian Pendidikan : Pendekatan Kuantitatif, Kualitatif, dan R\&D. Penerbit Alfabeta. Bandung.

Sri Haryanti, SSt., Msi., Seno Wibowo, SST. 2018. Pengembangan Almari Penyimpanan Terstandar untuk Perawatan Mikroskop di Laboratorium Jurusan Kesehatan Lingkungan. Politeknik Kesehatan Kementerian Kesehatan. Yogyakarta.

Syamswisna. 2011. Penggunaan Spesimen Herbarium Tumbuhan Tingkat Tinggi (Spermatophyta) Sebagai Media Praktikum Morfologi Tumbuhan. Jurnal Guru Membangun, Vol. 26 No. 2 Tahun 2011. Universitas Tanjung Pura. Pontianak.

Syamsiah, Nurhayati B., St. Fatmah Hiola. 2020. Pemanfaatan Spesimen Herbarium sebagai Media Pembelajaran bagi Guru-Guru IPA/Biologi di Kabupaten Enrekang. Jurnal Edukasi, Vol. 22, No. 1, April 2020.

Titi Kolimo. 2014. Panduan Teknis Pengumpulan Herbarum Rotan. Badan Penelitian Dan Pengembangan Kehutanan Pusat Penelitian Dan Pengembangan Konservasi Dan Rehabilitasi Bogor. Bogor.

Vincent D. Roth. 1972. A Miniaturized Plant Press And Herbarium. University Of California Press Vol. 34 Issue 9 (December 1972). Https://Online.Ucpress.Edu/Abt/Article-Split/34/9/535/9667/A-MiniaturizedPlant-Press-And-Herbarium 